\title{
Hydrogeophysical Investigation for Groundwater in Lokoja Metropolis, Kogi State, Central Nigeria
}

\author{
Omali Aurelius Ojoina ${ }^{1}$ \\ ${ }^{1}$ Department of Earth Sciences, Kogi State University, Anyigba, Nigeria \\ Correspondence: Omali Aurelius Ojoina, Department of Earth Sciences, Kogi State University, Anyigba, Nigeria. \\ Tel: 234-08-035-312-958. E-mail: omaliaurelius@yahoo.com
}

Received: November 11, 2013 Accepted: November 30, $2013 \quad$ Online Published: January 26, 2014

doi:10.5539/jgg.v6n1p81 URL: http://dx.doi.org/10.5539/jgg.v6n1p81

\begin{abstract}
Geophysical investigation for groundwater in Lokoja metropolis using vetrtical electrical sounding (VES) has been carried out. The objectives are to determine the aquifer types, depth to aquiferous zones and geoelectric layers. These are aimed at combating the incessant borehole failures caused due to poor exploration for groundwater in the area. Result of the VES indicate unconfined aquifers formed within weathered basement and the weathered/fractured basement aquifers. The survey delineated a maximum of four geoelectric layers which corresponds to the topsoil, weathered basement, weathered fractured basement and the fresh basement.The weathered basement aquifer occurs within 3 - layer and 4 - layer lithologic sections. The sections indicate a 3 layer A and H-type curves and a 4 - layer AA-type curves. The resistivity of the weathered basement aquifer in the 3 - layer lithologic sections range between $6.81 \Omega \mathrm{m}$ and $166.23 \Omega \mathrm{m}$, a depth range of $3.99 \mathrm{~m}$ to $22.26 \mathrm{~m}$ and a thickness of between $3.40 \mathrm{~m}$ and $6.14 \mathrm{~m}$ while the 4 - layer sections indicate resistivity varying from 316.62 $\Omega \mathrm{m}$ to $750 \Omega \mathrm{m}$, a depth ranging from $18 \mathrm{~m}$ to $25 \mathrm{~m}$ and a thickness of between $5.0 \mathrm{~m}$ and $6.70 \mathrm{~m}$. The weathered/fractured aquifer occurs within 4 - layer lithologic sections. The aquifer shows a 4 - layer AA-type geoelectric model with a resistivity range of $277.60 \Omega \mathrm{m}$ to $317.50 \Omega \mathrm{m}$, a thickness ranging between $3.0 \mathrm{~m}$ and $3.7 \mathrm{~m}$ and a depth varying from $17 \mathrm{~m}$ to $19.20 \mathrm{~m}$. Hence, groundwater in Lokoja is stored in weathered regoliths and in fractured Basement rocks.
\end{abstract}

Keywords: geophysical, groundwater, aquifers, lithologic sections, regoliths, Lokoja

\section{Introduction}

The Lokoja metropolis has witnessed an upsurge in industrial development and an increase in human population since it became the capital of Kogi State in 1991. Hence, the demand for potable water for human consumption, domestic uses, industrial and agricultural needs has grown rapidly.

Presently, the state government supplies the metropolis, surface water from the River Niger through her Lokoja Great Water Works (LGWW) programme. However, the supply has been inadequate to the extent that some inhabitants especially the less privilege depend on untreated surface water while other proportion of the populace and few private establishments and government organizations use groundwater abstracted from hand-dug wells, shallow wells and deep boreholes in some areas as supplement.

According to Philip Kearey (2001), groundwater is the water in porous rocks beneath the water table. In other worlds, it is the water that is contained in aquifer. An aquifer is any geologically deposited material which is porous and permeable, saturated with water and allows pumping of the water for economic use. Groundwater is relatively pure and grossly protected from surface pollutants due to its depth of storage and natural filtration process through the different subsurface layers (soil horizons). On the other, surface water is prone to high level of pollution from anthropogenic activities including human wastes, refuse dumps, effluent from industrial discharge and natural activity such as flood. Because groundwater is widely known to be more hygienic than surface water, the possibility of utilizing it as a source of water supply for public use is always attractive (Abdullahi et al., 2005). Interestingly, the volume of groundwater is enormous. Buchanan (1983) puts its volume at 2000 times that of the volume of water in all world's rivers at any given time. Therefore, groundwater development is sine qua non to supplement the expensive surface water treatment.

Geo-Hydro Tech (2008), Geobez Resources Ltd (2007), Leo Flinch Nig Ltd (2008) and Gbemi (2007) 
investigated the subsurface within Lokoja area using the electrical resistivity method of geophysical investigations. Bayode et al. (2007) carried out a geophysical investigation for groundwater in Ejigbo and its environs and delineated four subsurface geologic units. The survey revealed a good correlation between the lithological logs from selected boreholes and the geoelectric sequence and the bedrock structure. Olorunfemi and Fasuyi (1993) delineated five types of aquifer in the Basement Complex of southwestern Nigeria using geophysical survey means, namely: (I) The weathered layer aquifer, (II) Weathered/fractured (unconfined) or partly weathered aquifer, (III) Weathered/fractured (confined) aquifer, (IV) Weathered/fractured (unconfined)/fractured (confined) aquifer and (V) Fractured (confined) aquifer.

Mbiimbe et al. (2010) worked on groundwater exploration in a Basement complex terrain using electrical resistivity sounding in Rimi Gado area, Nigeria. They concluded that the study has helped in the identification of aquiferous units and has provided an understanding of aquifer dimensions especially the thickness of the weathered mantle, the depth to bed rock and the fractured zones which are required for locating points with high potentials for groundwater occurrence. Ochuko (2011) in his investigation on the groundwater exploration of Oleh, Nigeria, using electrical resistivity method, noted that the result of the study in comparison with lithologic logs from existing boreholes showed a four layered formation. Similar studies carried out in other parts of the world include those of Hani Al-Amoush (2012), Narasimha (2011) and Telford et al. (1990).

The Vertical Electrical Sounding (VES) survey method of geophysical prospecting has been used in this study. The success of the method is due to the variation of conductivity within the earth's subsurface layers, which in turn affects the distribution of electric potential. The degree of this effect depends on the size, shape, location and bulk electrical resistivity of the subsurface layers. The bulk electrical resistivity depends on the mineralogy of the rocks and its containing fluids (William, 1997).

In crystalline rocks such as those found in the study area, electrical current is conducted mainly along joints, faults and fissures. The presence of water in these fractures decreases the electrical resistivity of the layers containing the fissures. Therefore, low resistivity values indicate possible water saturated formation.

The development of groundwater in Lokoja metropolis is faced with problems of failed hand-dug wells and boreholes arising from poor knowledge of the hydrogeophysical characteristics of the basement aquifers. However, inorder to provide background information for future groundwater development as means of reducing incidences of boreholes failures, a systematic hydrogeophysical investigation of the metropolis has been carried out.

The objectives of this study include, the determination of aquiferous units and their thicknesses and the various geologic/geoelectric layers beneath the sounding stations.

\section{Topography}

Lokoja sub - basin, part of Mid Niger basin is characterized by undulating topography with limited flat terrain. This is typical of Mount Patti and Agbaja plateau which are the two main highlands in the area. Mount Patti is a linear NW - SE ridge parallel to Agbaja Plateau with an altitude of about $442.25 \mathrm{~m}$ both following the basin trend and perpendicular to the main axis of the Benue trough (Falconer, 1911). These highlands are capped by indurated and ferruginous sandstones. They also extend across the Niger River towards Bassa and terminating around Gboloko - Monzum area. The eastern, southwestern and southeastern parts of Lokoja area have altitudes ranging between 50 metres and 90 metres, and are underlain by Basement rocks (Figure 1).

\section{Geology and Hydrogeology}

The study area is dominantly underlain by the Precambrian Basement Complex. However, part of the area is underlain by Cretaceous sediments which unconformably overlie the Basement Complex.

Migmatite covers about half of the study area outcropping at the southwest, west, northwest and central parts of the area. The South and the southeast parts of the area are underlain by undifferentiated older granite, mainly porphyroblastic granite, granite gneiss with porphyroblastic gneiss and fine grained biotite granite. The northern part of the area is made of ridges (Mount Patti) of Cretaceous sediments of the Southern Bida Basin (Lokoja Sub- Basin). The ridges are dominantly composed of feldspathic sandstone and siltstone which are separated by the biotite hornblende gneiss. Thick alluvial deposit occurs around the Rivers Niger and Benue drainage system (Figure 2). Lokoja, located in the plains of River Niger at the confluence with River Benue, falls within both the crystalline and sedimentary hydrogeological provinces.

The study area contains the confluence point where River Niger and River Benue meet. The Niger River basin is a 2.3 million $\mathrm{km}^{2}$ bound by latitudes $5^{\circ} \mathrm{N}$ and $23^{\circ} \mathrm{N}$ and longitudes $12^{\circ} \mathrm{W}$ and $17^{\circ} \mathrm{E}$. The river rises in Guinea and flows for about 4,200 km through Mali, Niger and Nigeria before reaching the Atlantic Ocean. Its main tributary, 
the Benue River, flows west from the Cameroon and joins the Niger at Lokoja. Precipitation in the basin is variable. It ranges from $2,700 \mathrm{~mm} / \mathrm{yr}$ close to the river mouth to almost none in the desert parts. An overall water balance shows that out of the $48,000 \mathrm{~m}^{3} / \mathrm{s}$ of water that enters the Niger River basin through precipitation, 42,900 $\mathrm{m}^{3} / \mathrm{s}(89 \%)$ is lost in overland flow and $1,100 \mathrm{~m}^{3} / \mathrm{s}(2 \%)$ in stream flow, leaving only $4,000 \mathrm{~m}^{3} / \mathrm{s}(9 \%)$ at the river mouth (Olivera et al., 1995).

The groundwater availability in crystalline rocks in the area is greatly dependent on the degree of weathering and fracturing of the rocks and the interconnectivity of the fractures. The area is generally drained by Rivers Niger, Benue and River Mimi, a tributary of River Niger. The mean annual humidity is about $70 \%$ (Meteorological Department, Federal Ministry of Aviation, 2007). Aquifers found in this area are recharged directly by precipitation but can also be recharged by infiltration from Rivers Niger, Benue and Mimi. Groundwater abstraction is mainly by hand-dug wells, boreholes and from springs.

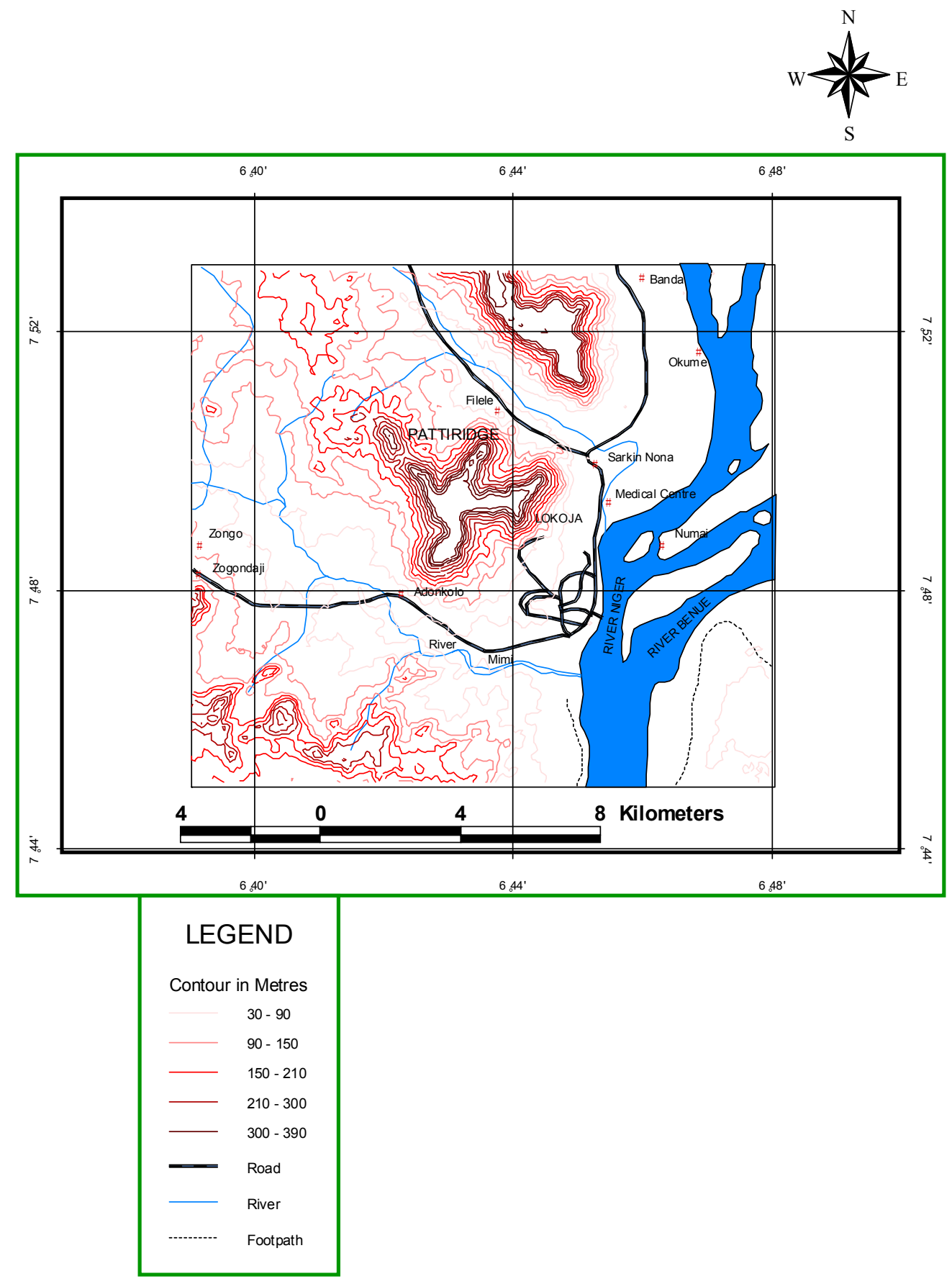

Figure 1. Topographic map of Lokoja area 




Figure 2. Geology map of Lokoja area (Source: this work)

\section{Methodology}

A total of seventeen (17) vertical electrical soundings (VES) were carried out in this study.Terrameter SAS 300C was used to carry out the resistivity measurement in the field. Schlumberger configuration was adopted with maximum half-current electrode spread $(\mathrm{AB} / 2)$ of $60 \mathrm{~m}$ while the half potential electrode separation $(\mathrm{MN} / 2)$ was maintained between $0.5 \mathrm{~m}$ and $7.5 \mathrm{~m}$. The VES curves were quantitatively interpreted by partial curve matching and computer iteration techniques, using resound, a computer programme based on linear filter theory (Zohdy, 1989). The principle of the resistivity method is that electric current is passed into the ground through two outer electrodes, and the resultant potential difference is measured across two inner electrodes that are arranged in a straight line, symmetrically about a centre point.

The potential difference to the current ratio is displayed by the terrameter as resistance. A geometric factor in meters $(\mathrm{m})$ is calculated as a function of the electrode spacing. The resistance readings obtained from the Terrameter is multiplied by this factor to give an apparent resistivity value. The electrode spacing is progressively increased, keeping the centre point of the electrode array fixed.

Lithologic sections exposed in some open hand-dug wells served as auxiliaries in the interpretation of subsurface 
layers.

\section{Results and Discussion}

A total of 17 VES was carried out in the study area. The summary of the results are presented in Tables 1 and 2 below.

Table 1. Summary of the weathered basement aquifer and its characteristics

\begin{tabular}{|c|c|c|c|c|c|c|}
\hline Station number & $\begin{array}{l}\text { Type of } \\
\text { geo-electric } \\
\text { model }\end{array}$ & Layers & $\begin{array}{l}\text { Depth } \\
\text { range } \\
(\mathrm{m})\end{array}$ & $\begin{array}{l}\text { Thickness } \\
\text { range }(\mathrm{m})\end{array}$ & $\begin{array}{l}\text { Resistivity } \\
\text { range }(\Omega \mathrm{m})\end{array}$ & $\begin{array}{l}\text { Inferred } \\
\text { lithology }\end{array}$ \\
\hline \multirow{3}{*}{$\begin{array}{c}\text { VES station } \\
1,2,3,4,5,6,7,8,9,10,11,12, \& 16\end{array}$} & \multirow{3}{*}{$\begin{array}{c}\text { 3-layer (A, } \\
\text { H-type } \\
\text { curves) }\end{array}$} & $\begin{array}{l}\text { First } \\
\text { layer }\end{array}$ & $\begin{array}{c}0.60- \\
14\end{array}$ & $11.8-14$ & $\begin{array}{l}25.92- \\
1092.09\end{array}$ & $\begin{array}{l}\text { Topsoil } \\
\text { (clay/laterite) }\end{array}$ \\
\hline & & $\begin{array}{l}\text { Second } \\
\text { layer }\end{array}$ & $\begin{array}{l}3.99- \\
22.16\end{array}$ & $3.4-6.14$ & $\begin{array}{l}6.81- \\
166.23\end{array}$ & $\begin{array}{l}\text { Weathered } \\
\text { basement } \\
\text { (aquifer) }\end{array}$ \\
\hline & & $\begin{array}{l}\text { Third } \\
\text { layer }\end{array}$ & - & - & $\begin{array}{c}33.45 \\
-7724.31\end{array}$ & $\begin{array}{l}\text { Competent } \\
\text { basement }\end{array}$ \\
\hline \multirow{4}{*}{ VES station $13,15, \& 17$} & \multirow{4}{*}{$\begin{array}{c}\text { 4-layer (AA, } \\
\text { HA type } \\
\text { curves) }\end{array}$} & $\begin{array}{l}\text { First } \\
\text { layer }\end{array}$ & $6-15$ & $6-15$ & $58-664$ & $\begin{array}{l}\text { Topsoil } \\
\text { (clay/laterite) }\end{array}$ \\
\hline & & $\begin{array}{l}\text { Second } \\
\text { layer }\end{array}$ & $\begin{array}{l}13- \\
18.5\end{array}$ & $3.3-8.8$ & $\begin{array}{l}66.84- \\
398.49\end{array}$ & Clay/laterite \\
\hline & & $\begin{array}{l}\text { Third } \\
\text { layer }\end{array}$ & $\begin{array}{l}18- \\
25\end{array}$ & $5-6.7$ & $\begin{array}{c}316.62- \\
750.20\end{array}$ & $\begin{array}{l}\text { Weathered } \\
\text { basement } \\
\text { (aquifer) }\end{array}$ \\
\hline & & $\begin{array}{c}\text { Fourth } \\
\text { layer }\end{array}$ & - & - & $\begin{array}{c}505.53- \\
1930.04\end{array}$ & $\begin{array}{l}\text { Competent } \\
\text { basement }\end{array}$ \\
\hline
\end{tabular}

Table 2. Summary of the weathered/fractured basement aquifer and its characteristics

\begin{tabular}{ccccccl}
\hline $\begin{array}{c}\text { Station } \\
\text { number }\end{array}$ & $\begin{array}{c}\text { Type of } \\
\text { geo-electric } \\
\text { model }\end{array}$ & Layers & $\begin{array}{c}\text { Depth range } \\
(\mathrm{m})\end{array}$ & $\begin{array}{c}\text { Thickness } \\
\text { range }(\mathrm{m})\end{array}$ & $\begin{array}{c}\text { Resistivity } \\
\text { range }(\Omega \mathrm{m})\end{array}$ & Inferred lithology \\
\hline & & $\begin{array}{c}\text { First } \\
\text { layer }\end{array}$ & $8-10$ & $8-10$ & $20-79.40$ & Laterite \\
VES & 4-layer & Second & $14-15.5$ & $4-7.5$ & $41.50-$ & Weathered \\
stations & (AA-type & layer & & & 99.35 & basement (aquifer) \\
$6 \& 14$ & curves) & Third & $17-19.2$ & $3-3.7$ & $277.6-$ & Weathered/fractured \\
& & layer & & -317.5 & basement (aquifer) \\
& & Fourth & - & $491-89-$ & $\begin{array}{l}\text { Competent } \\
\text { basement }\end{array}$ \\
\hline
\end{tabular}

From the result of the vertical electrical sounding (VES), two types of aquifer were delineated, namely; the weathered basement aquifer and weathered/fractured aquifer. The weathered basement aquifer was shown by VES 1 to 17 while weathered/fractured aquifer was revealed by VES stations 6 and 14. Five (5) out of the seventeen (17) VES curves revealed a 4 - layer geoelectric model (VES 6, 13, 14, 15 \& 17) and the characteristic geoelectric signatures are AA- and HA- type curves, while the remaining twelve (12) indicated a 3 - layer geoelectric model (VES 1, 2, 3, 4, 5, 7, 8, 9, 10,11, 12 \& 16) and the characteristic geoelectric signatures are $\mathrm{H}$ - and $\mathrm{A}$ - type curves. These are shown in Tables 1 and 2 above.

The A - type curve represents a subsurface condition in which there is an increase in resistivity values from the topsoil to the bedrock $(\rho 1<\rho 2<\rho 3)$. This represented by Figures 9 and 10 . The $\mathrm{H}-$ type curve represents a 
subsurface whereby the resistivity of the first layer is greater than the second layer while the resistivity of the second layer is less than the third layer $(\rho 1>\rho 2<\rho 3)$. This represented by Figures $3,4,5,6,7,10,11,12,13$ and 14. The AA - type curve represents a subsurface composed of four layers in which there is an increase in resistivity from the first layer to the competent basement $(\rho 1<\rho 2<\rho 3<\rho 4)$. This type curve is expressed by Figures 8,15 and 16 . The HA - type curve shows a subsurface in which the resistivity of the first layer is greater than the second layer, that of the second layer is less than the third layer and the resistivity of the third layer is less than the fourth layer $(\rho 1>\rho 2<\rho 3<\rho 4)$. This is shown by Figures 17 and 19 .

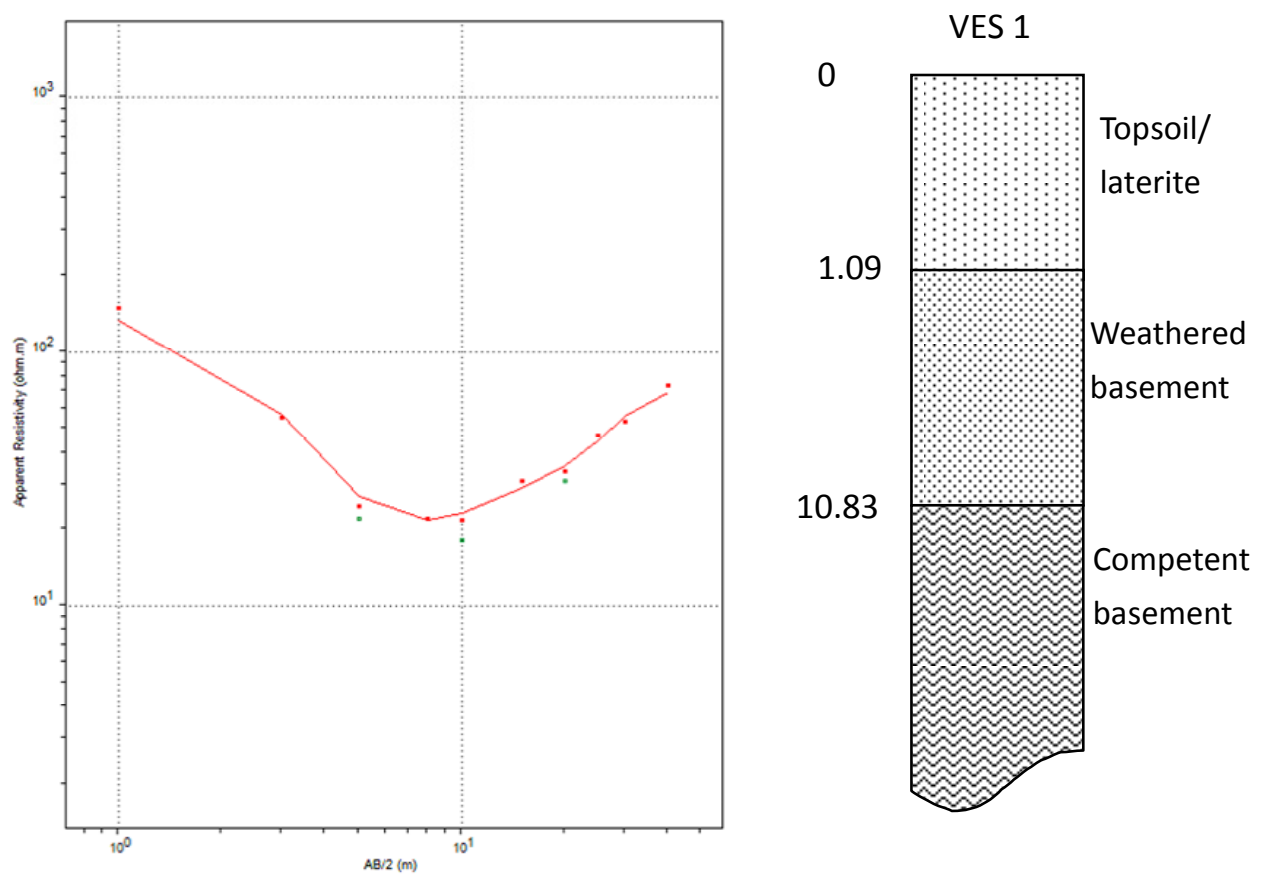

Figure 3. Vertical electrical sounding station 1

The topsoil generally comprises clay and laterite and constitutes the zone of aeration (phreatic zone). This zone contributes to groundwater development as it serves as a conduit through which meteoric water infiltrates the subsurface to form groundwater.The weathered basement aquifer in the study area formed the second layer for the 3 - layer formations. The depth of the layer ranges from $3.99 \mathrm{~m}$ to $22.16 \mathrm{~m}$ and the thickness ranges from 3.1 $\mathrm{m}$ to $6.14 \mathrm{~m}$. The resistivity is in the range of $6.81 \Omega \mathrm{m}$ to $166.23 \Omega \mathrm{m}$ (Table 1 ). For the four layer formations, the weathered layer aquifer forms the third layer. The depth of the layer varies from $18 \mathrm{~m}$ to $25 \mathrm{~m}$, while the thickness ranges from $5 \mathrm{~m}$ to $6.7 \mathrm{~m}$ with a resistivity range of $316.62 \Omega \mathrm{m}-750.20 \Omega \mathrm{m}$. The groundwater yield of this aquifer type is determined by the degree of shaliness of the weathered zone. Low yield is encountered when the aquifer unit is clayey. This is because clay is not permeable to allow the flow of water. Sources of clay in Lokoja can be attributed to weathering of feldspar of the Lokoja Formation and the Basement rocks in the area. Inaddition, yield of the weathered aquifer is a function of the thickness of the regoliths and the interconnectivity of the grains that make up the regoliths.

The weathered/fractured aquifer forms the third layer in the four layer geoelectric model. The depth of the layer ranges from $17 \mathrm{~m}-19.2 \mathrm{~m}$, a thickness range of between $3 \mathrm{~m}$ and $3.7 \mathrm{~m}$ and a resistivity varying from $277.6 \Omega \mathrm{m}$ $-317.5 \Omega \mathrm{m}$ (Table 2). This zone underlies the weathered zone directly. The groundwater yield from this aquifer type could be high if the density of the fractures in the fractured column is high.

The fresh Basement Complex forms the last layer in the geoelectric section. The resistivity values of the competent basement for both aquifers vary from $33.45 \Omega \mathrm{m}-7724.31 \Omega \mathrm{m}$. Olayinka and Olurunfemi (1992) had reported that fresh Basement Complex has resistivity that exceeds $1000 \Omega \mathrm{m}$ but where it is fractured and water saturated, the resistivity reduces to less than $1000 \Omega \mathrm{m}$. Figures 3 to 19 below represent VES curves for the study area. 

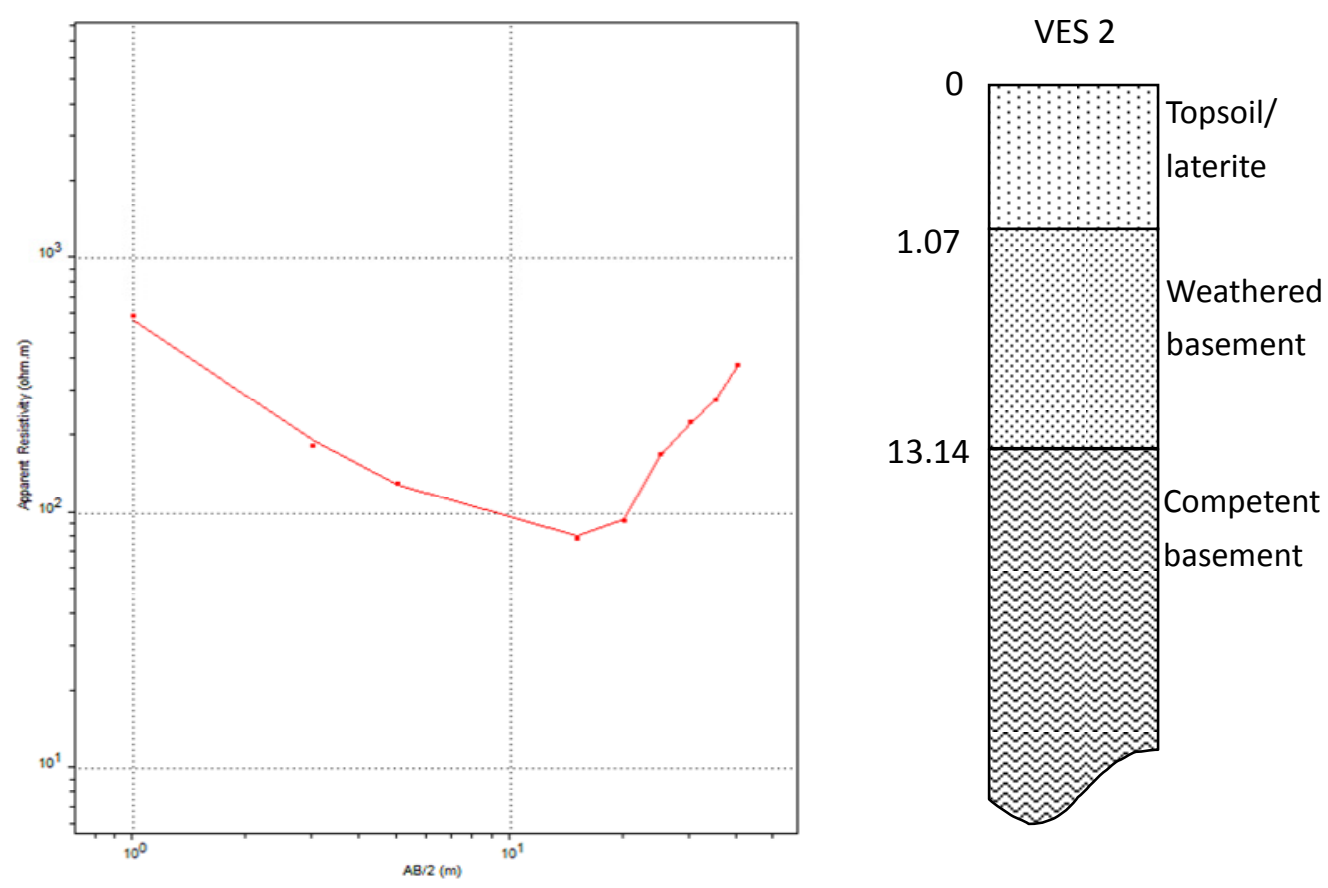

Figure 4. Vertical electrical sounding station 2
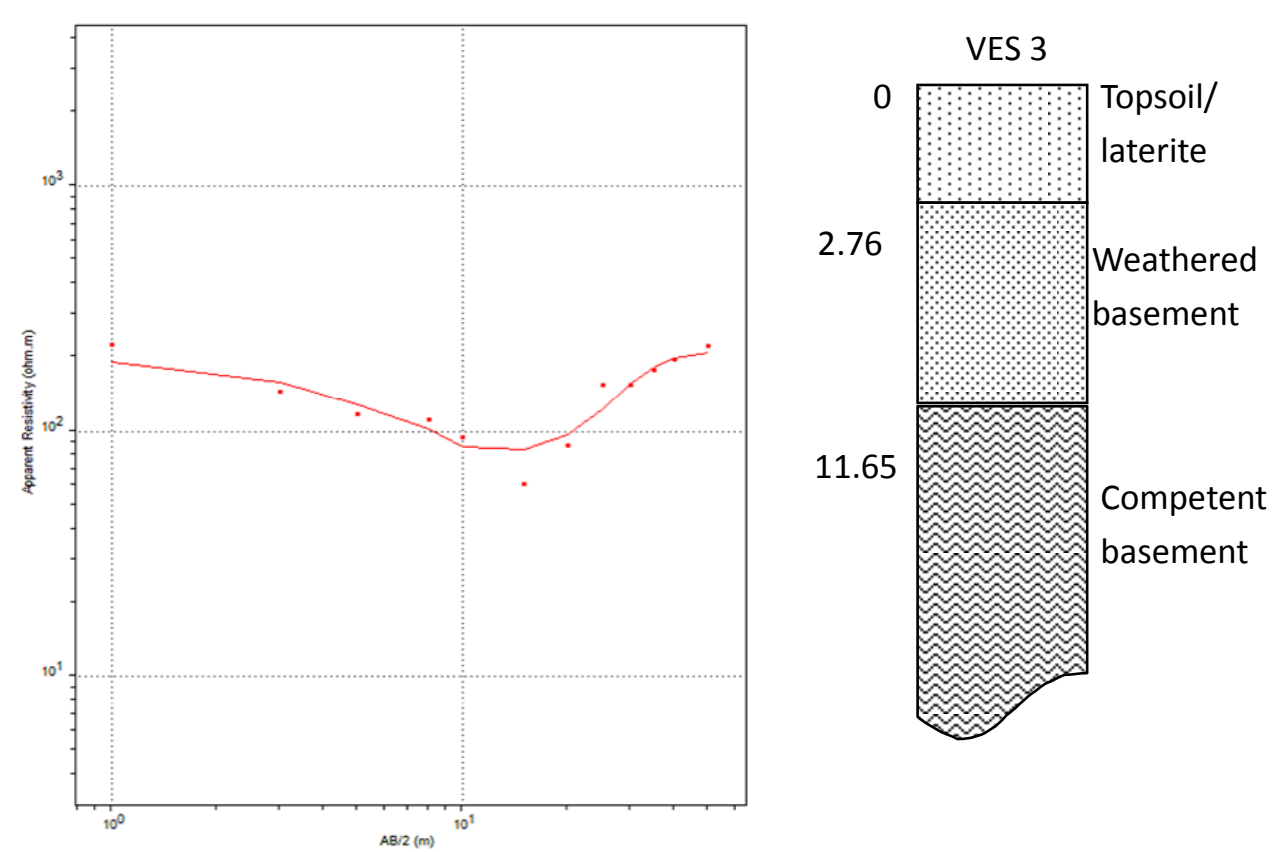

Figure 5. Vertical electrical sounding station 3 

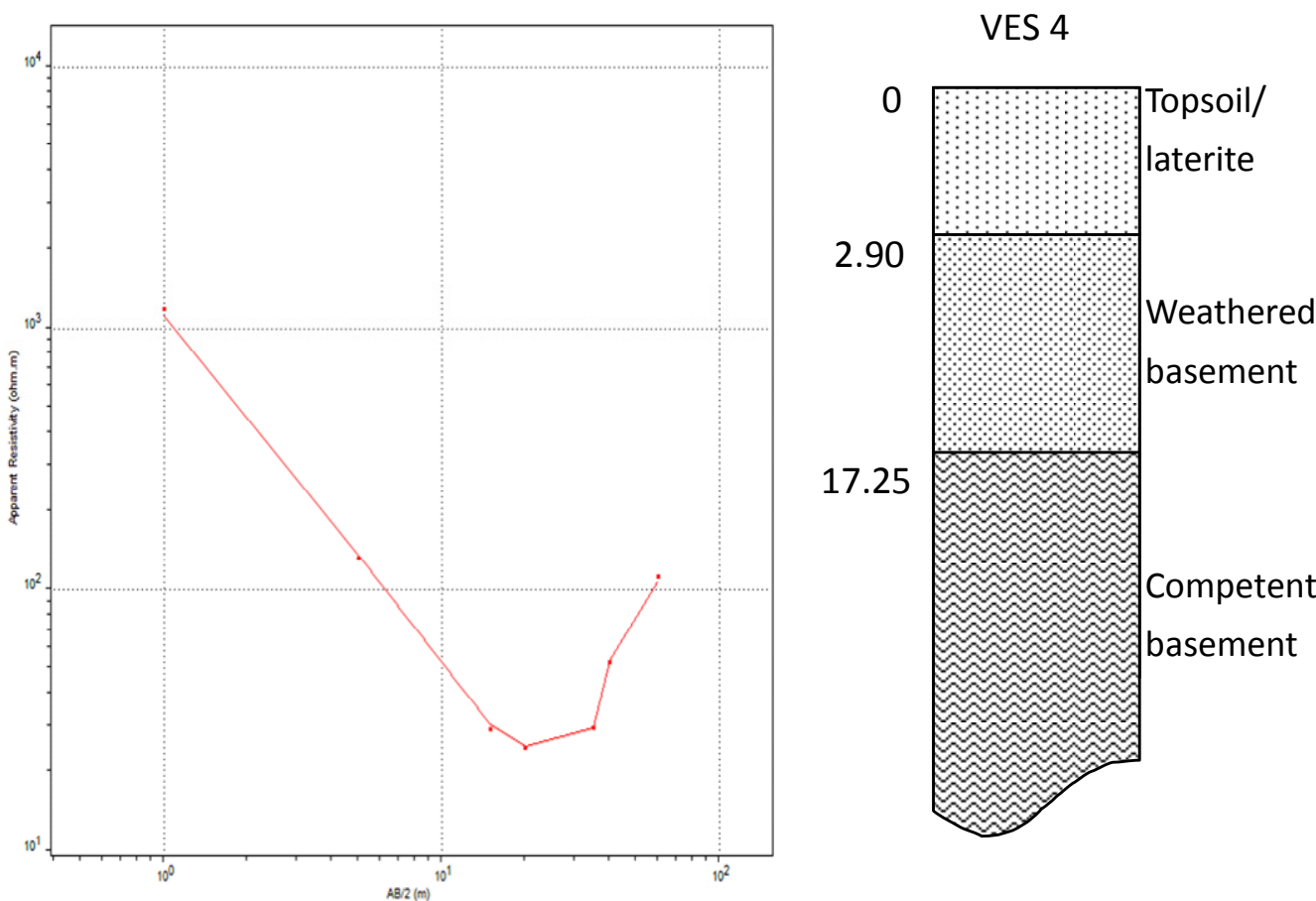

Figure 6. Vertical electrical sounding station 4
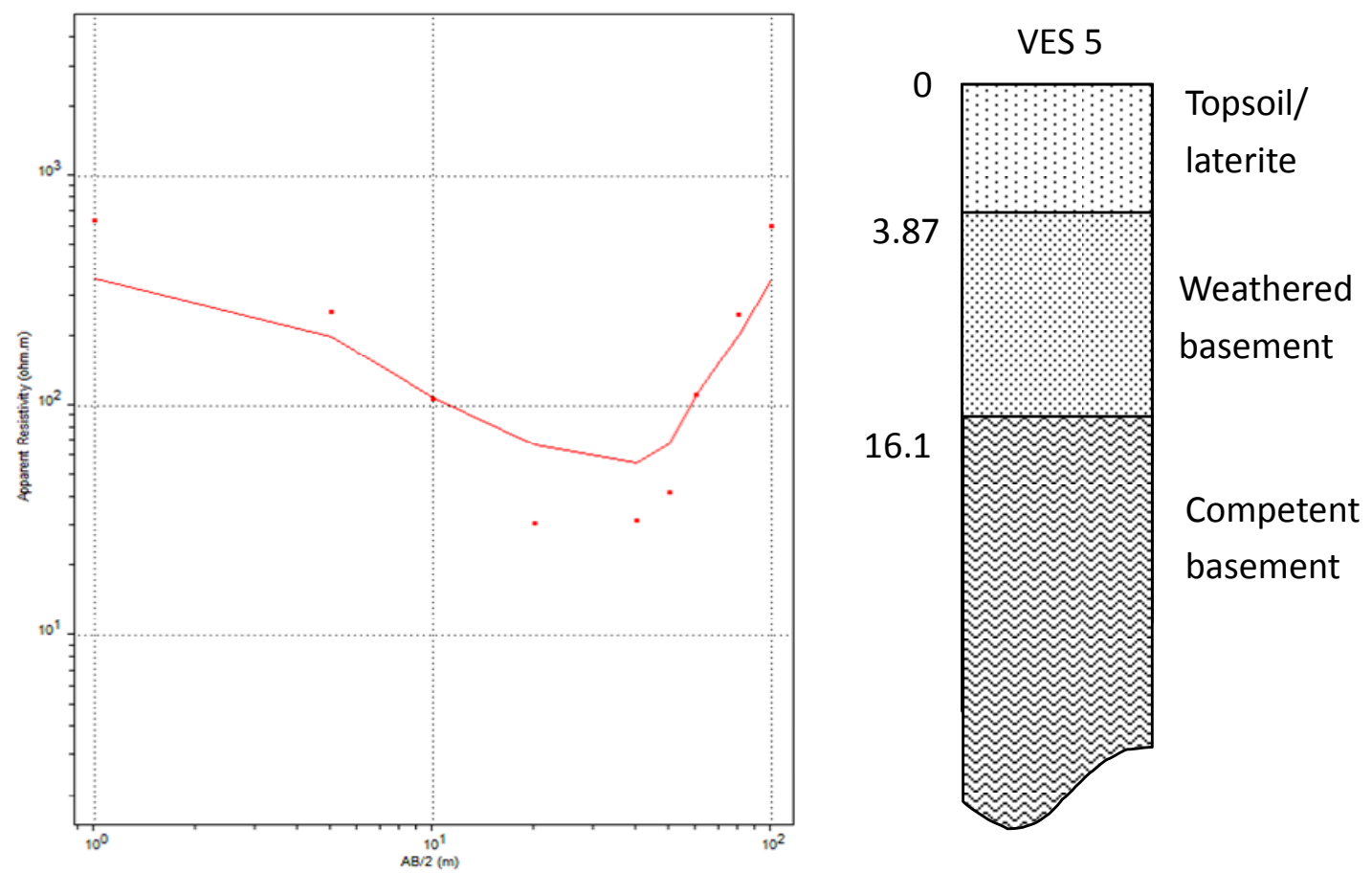

Figure 7. Vertical electrical sounding station 5 

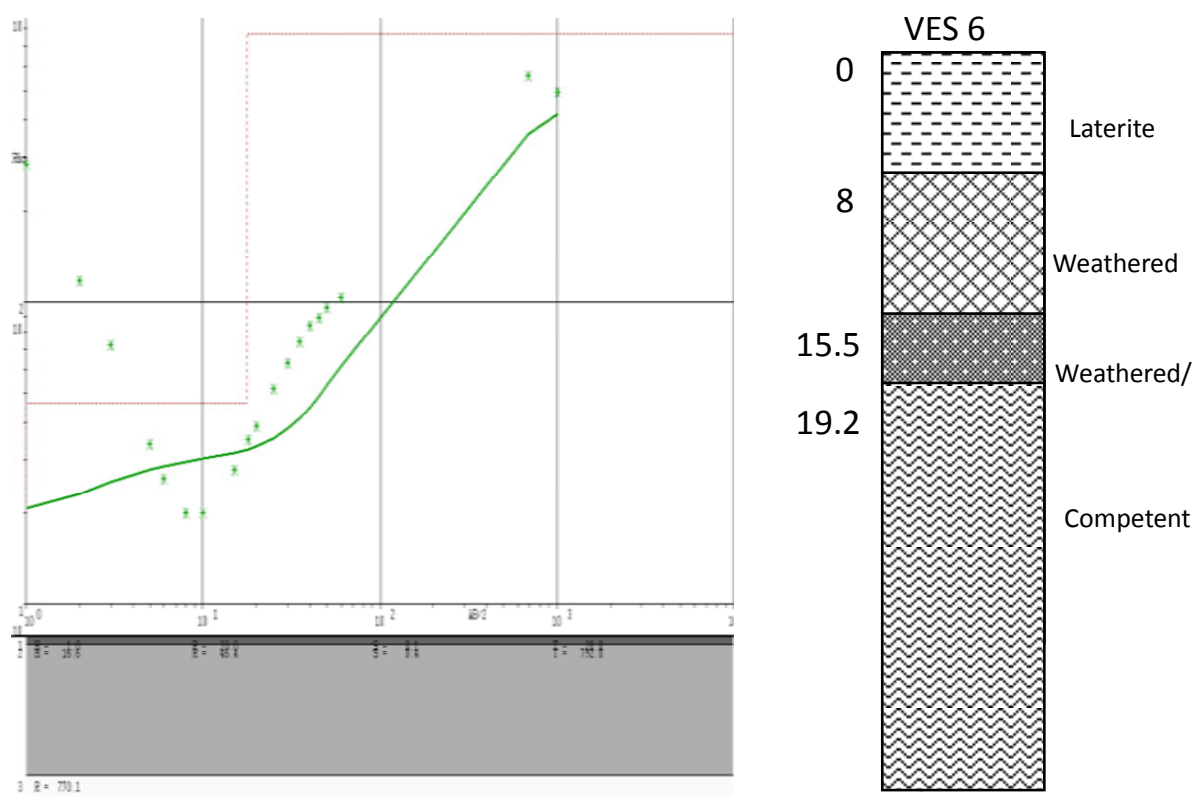

Figure 8. Vertical electrical sounding station 6
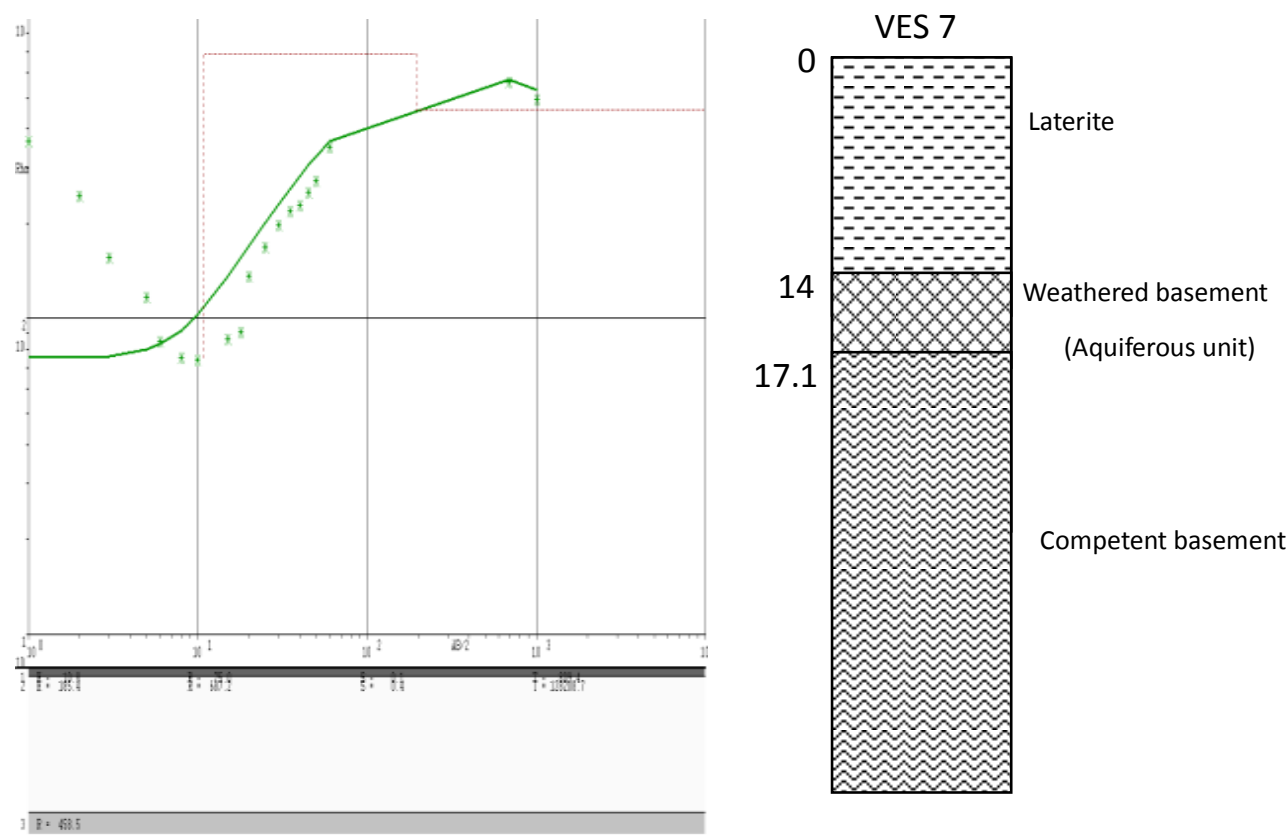

Figure 9. Vertical electrical sounding station 7 

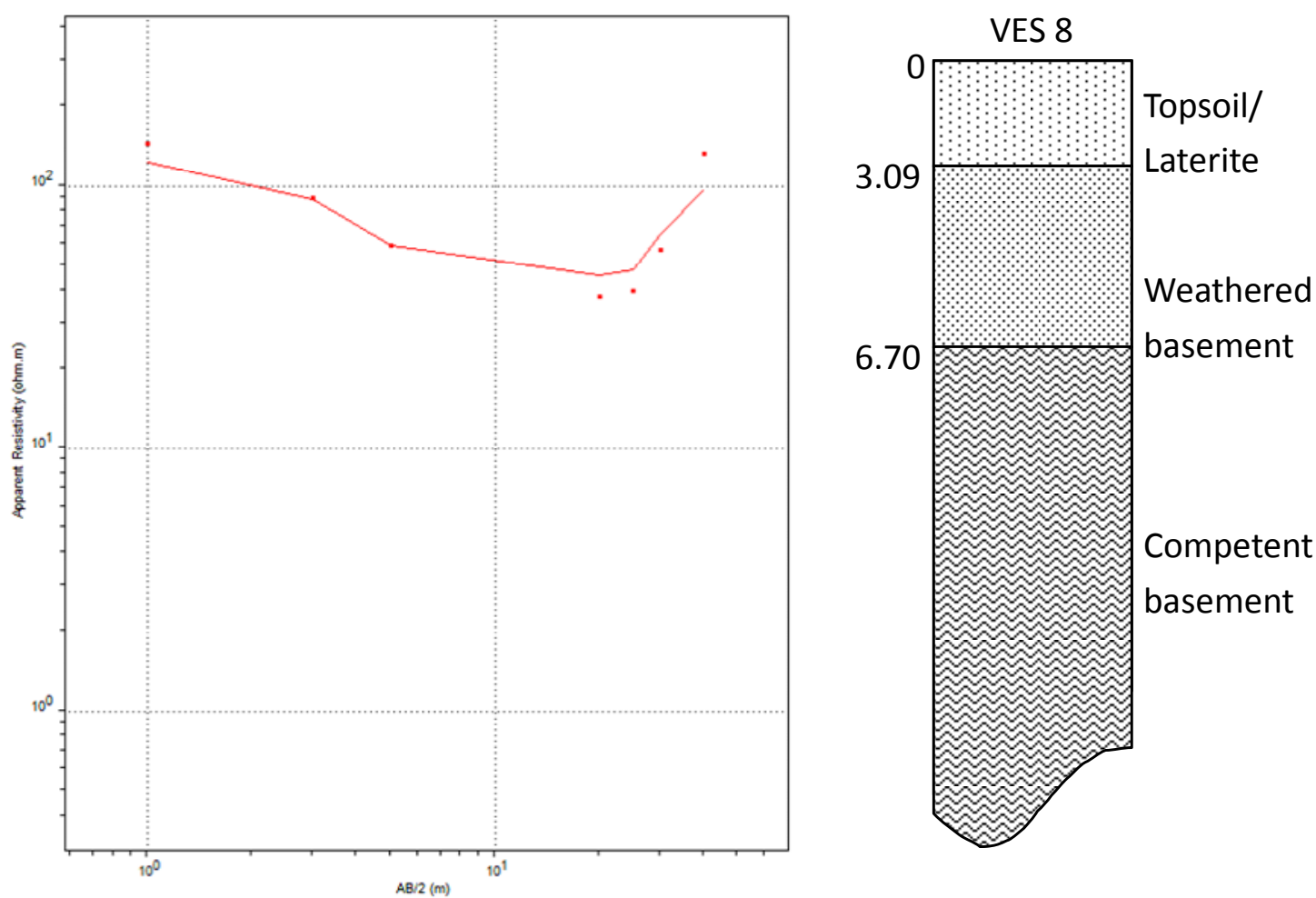

Figure 10. Vertical electrical sounding station 8
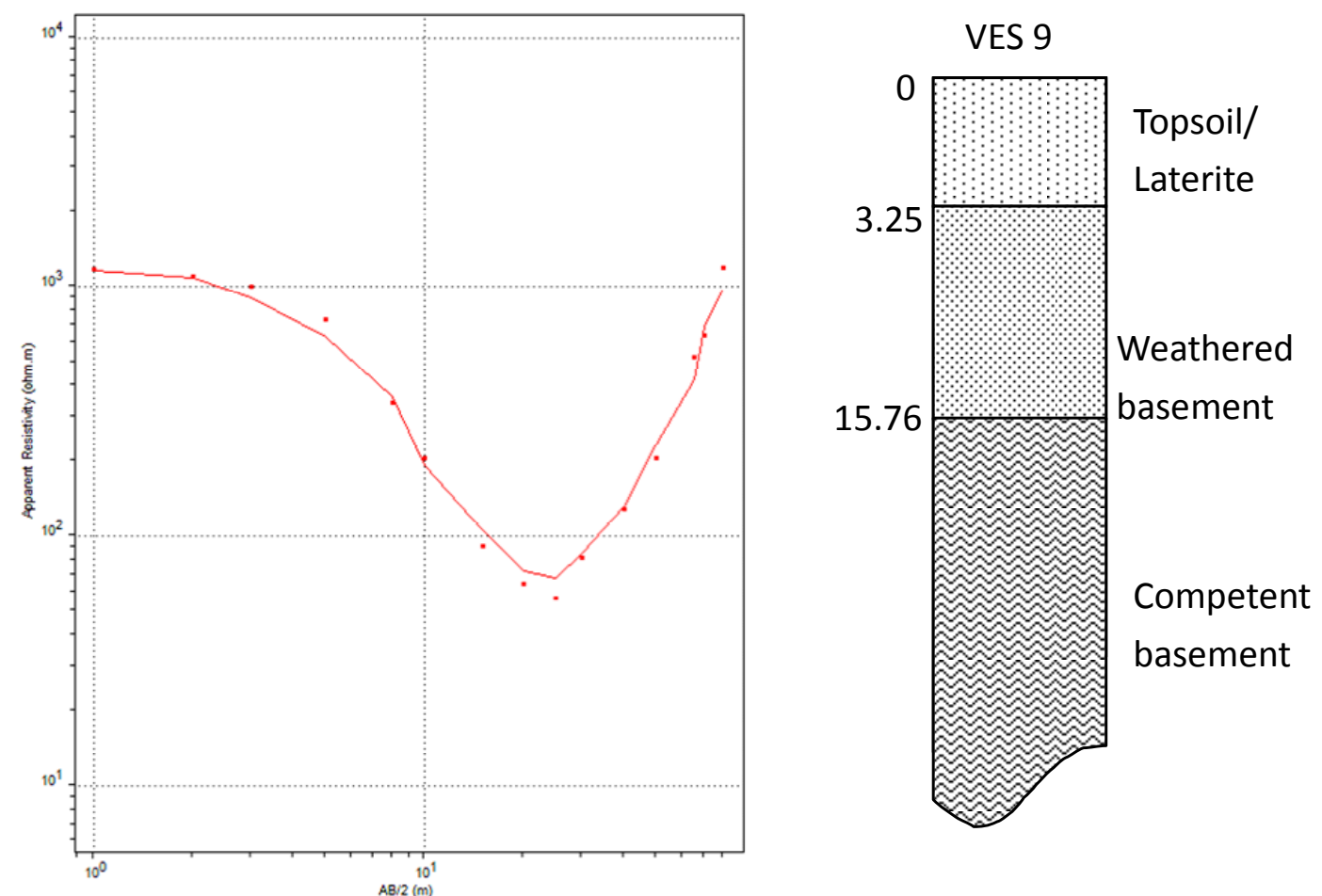

Figure 11. Vertical electrical sounding station 9 

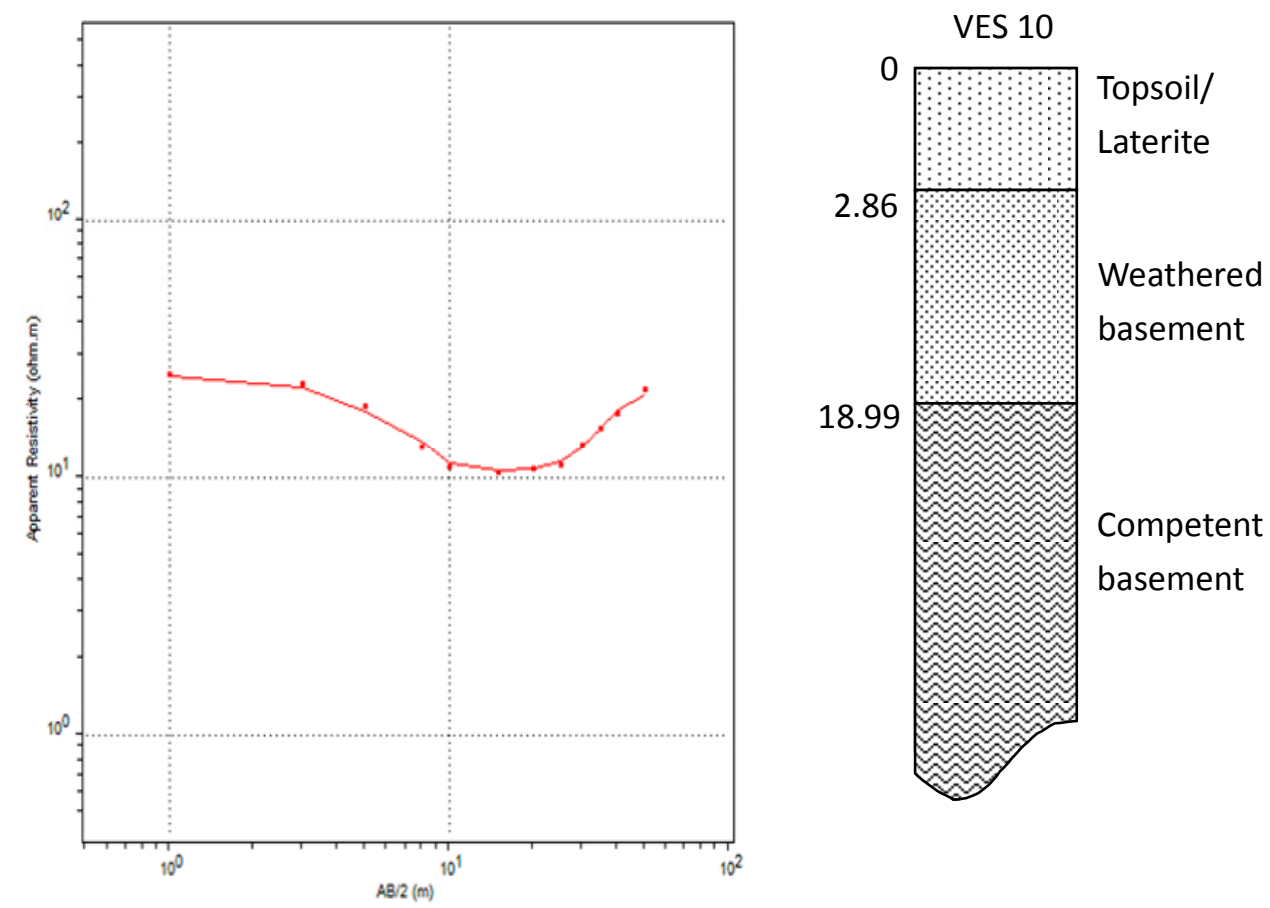

Figure 12. Vertical electrical sounding station 10
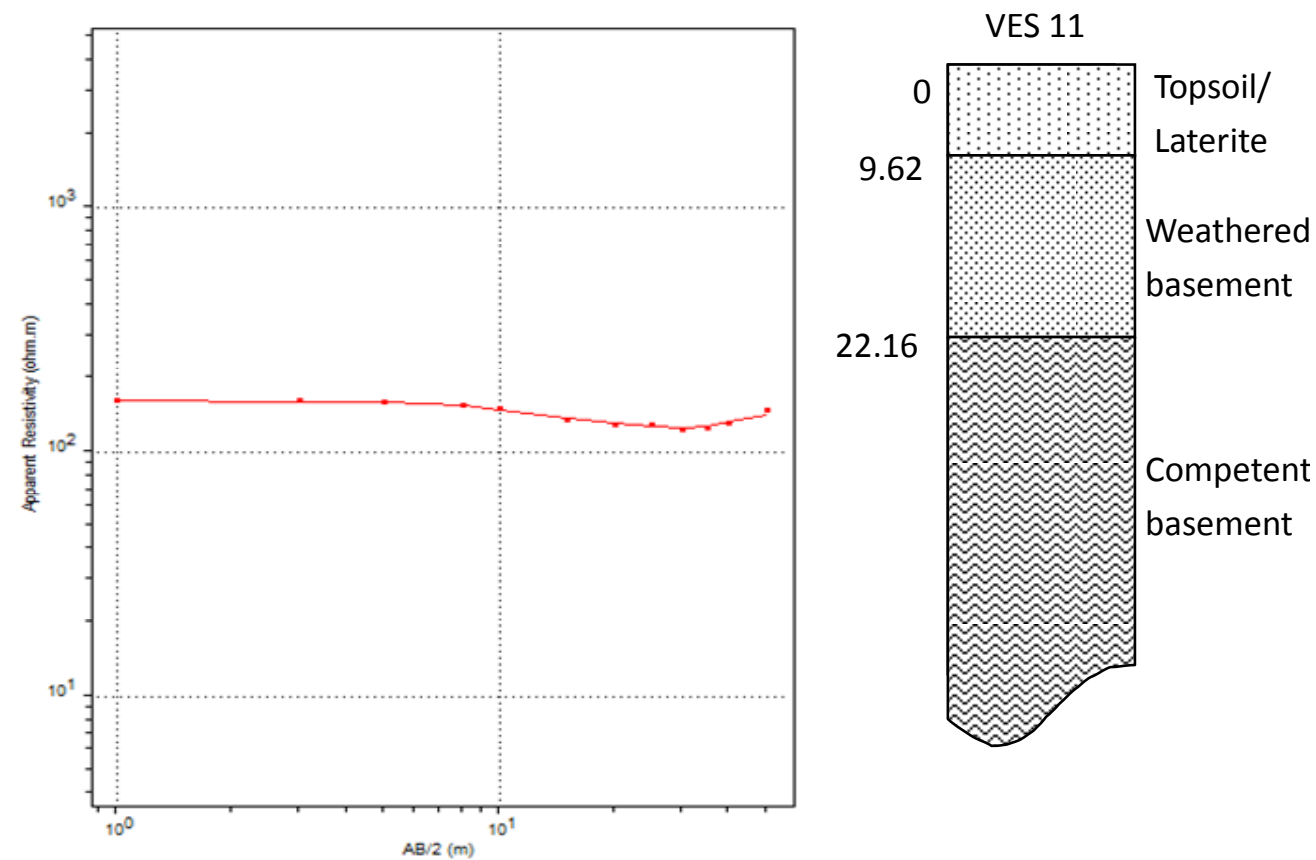

Figure 13. Vertical electrical sounding station 11 



Figure 14. Vertical electrical sounding station 12
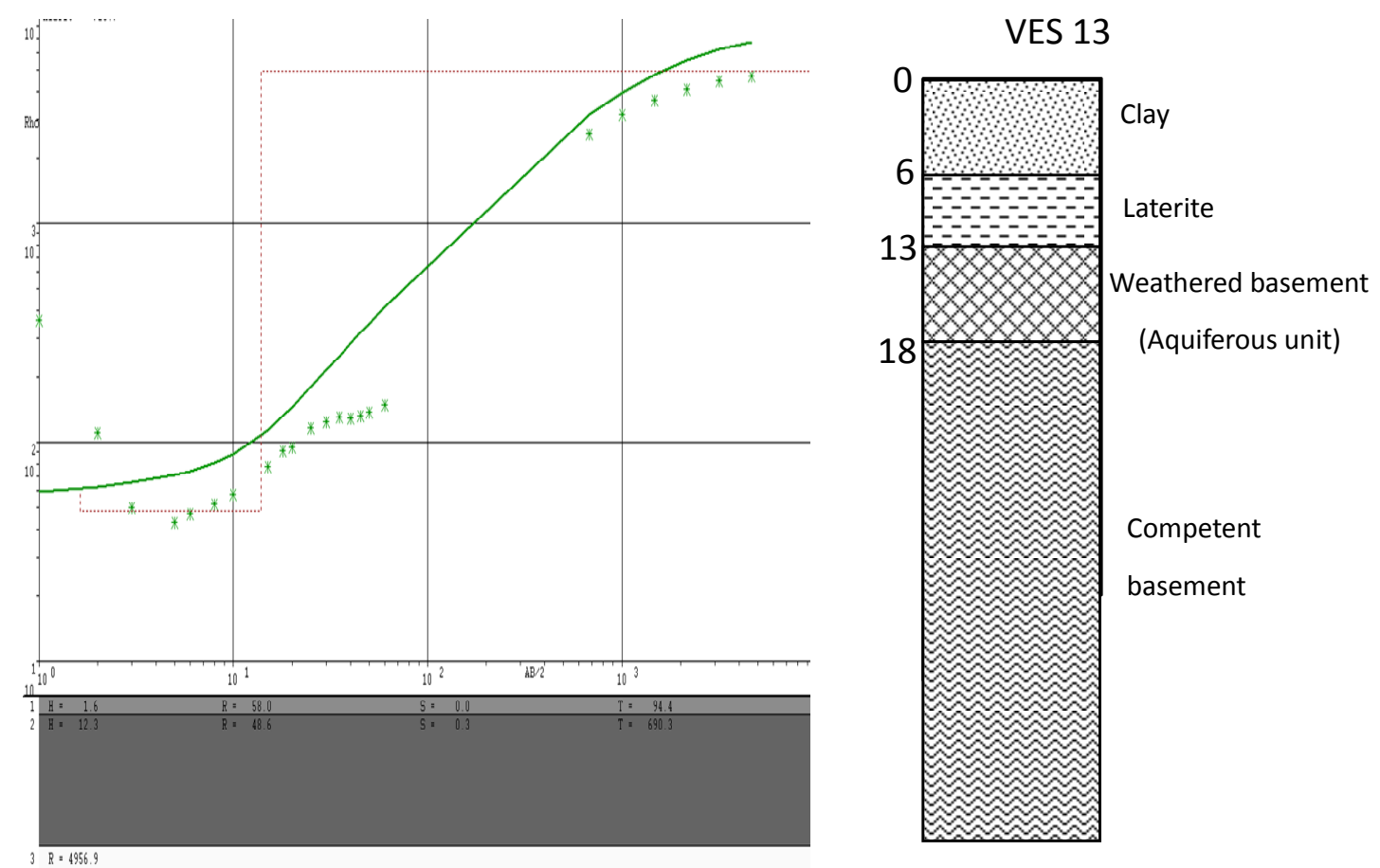

Figure 15. Vertical electrical sounding station 13 



Figure 16. Vertical electrical sounding station 14
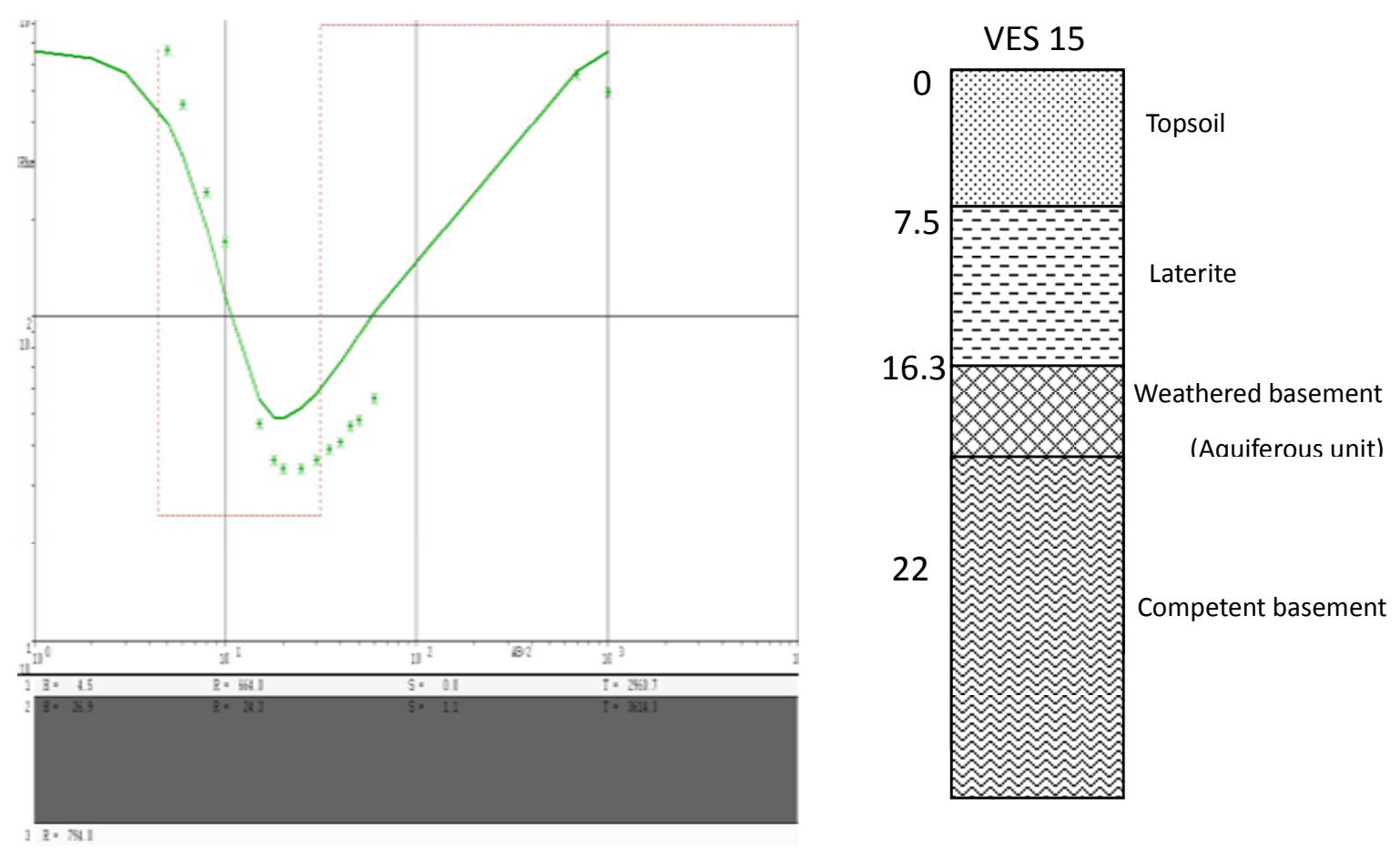

Figure 17. Vertical electrical sounding station 15 



Figure 18. Vertical electrical sounding station 16
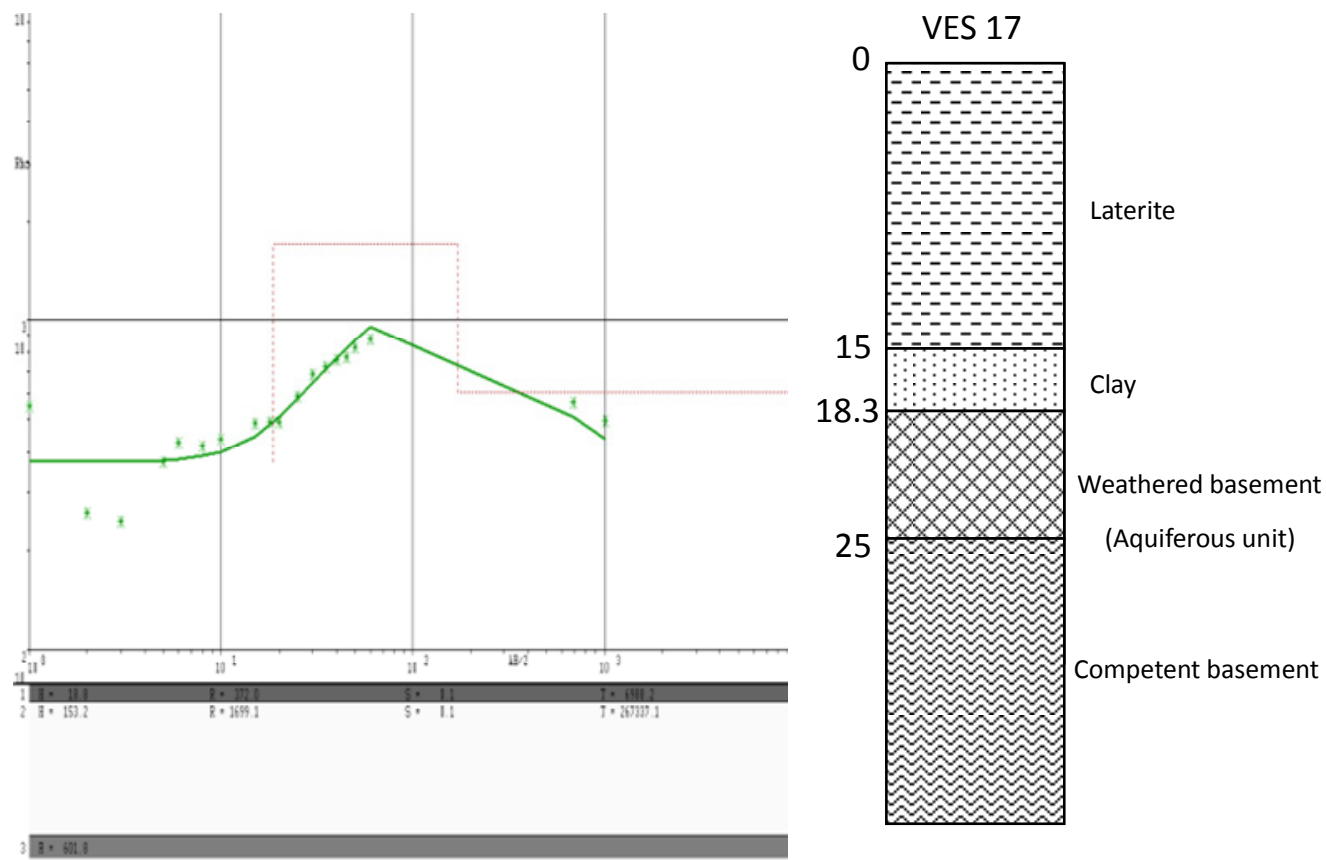

Figure 19. Vertical electrical sounding station 17

\section{Conclusion}

The VES carried out in the study area delineated two aquifer types, viz, the weathered aquifer and the fractured aquifer. These aquifers are thin in some of the localities while in other loctions they are appreciably thick, hence, enormous groundwater storage and discharge capacity. Groundwater development in the area is therefore, highly recommended.

\section{Acknowledgements}

I hereby acknowledge Prof. Boniface Egboka for supervising this research. Also I duely recognize the Education Trust Fund (ETF), for sponsoring the research and Kogi state university for creating an enabling environment for 
this particular study.

\section{References}

Abdullahi, A. S., Musa, S. M., \& Illiya, A. G. (2005). Aquifer depletion and groundwater situation in Damaturu, Northeastern Nigeria. Water Resour., 16, 59-64.

Al-Amoush, H. (2012). Hydro-Geophysical Investigations for the Purposes of Groundwater Artificial Recharge in Wadi Al-Butum Area, Jordan. Journal of Water Resource and Protection, 4(7), 507-515. http://dx.doi.org/10.4236/jwarp.2012.47059

Anomohanran, O. (2011). Underground water exploration of Oleh, Nigeria using the electrical resistivity method. Scientific Research and Essays, 6(20), 4295-4300.

Bayode, S., Ojo, J. S., \& Olorunfemi, M. O. (2008). Geophysical exploration for groundwater in Ejigbo and its environs, Southwestern Nigeria. Global Journal of Geological Sciences, 5(1). http://dx.doi.org/10.4314/gjgs.v5i1.18740

Buchanan, T. J. (1983). International Water Technology Conference and Exposition. (AUGA EXPO 83).

Falconer, J. D. (1911). The Geology and Geography of Northern Nigeria. MacMillan, London.

Gbemi, S. O. (2007). Geophysical investigation for groundwater within Otokiti Community, Lokoja, Kogi State. Unpublished report for Kogi State Government.

Geobez Resources Ltd. (2007). Geophysical investigation for groundwater within the premises of Directorate of Rural Development, Lokoja, Kogi State. Unpublished Report for Kogi State Government.

Geo-Hydro Tech. (2008). Geophysical investigation for groundwater off Ganaja Road, Lokoja, Kogi State. Unpublished Report for Moses Folurunsho.

Leo Flinch Nig. LTD. (2008). Geophysical investigation for groundwater within 250 Housing Estate Phase 1, Lokoja, Kogi State. Unpublished Report for Kogi State Government.

Mbilmbe, E. Y., Samaila, N. K., \& Akanni, D. K. (2010). Groundwater Exploration in a Basement Complex terrain using electrical Resistivity Sounding (VES): a case study of Rimin Gado town and Environs, Kano State North Central Nigeria. Continental Journal Earth Sciences, 5(1), 56-63.

Nigeria Meteorological Agency. (2007). Temperature and Relative Humidity. Annual Records by Nigeria Meteorological Agency, Lokoja Station, Kogi State, Nigeria.

Olayinka, A. I., \& Olorunfemi, M. O. (1992). Determination of geoelectrical characteristics in Okene area and implication for borehole siting. Journal of Mining and Geology, 28(2), 243-250.

Olivera, F., Mckinney, D. C., Maidment, D. R., Zichuan, Y., \& Reeds, S. (1995). Predicting the water balance of surface and groundwater resources over large areas. Paper presented at UNESCO symposium on Runoff computations for water projects, St. Petersburg, Russia, October 30 - November 3.

Olorunfemi, M. O., \& Fasuyi, S. A. (1993). Aquifer types and the geoelectric/hydrogeologic characteristic of part of the central basement terrain of Nigeria. Journal of Africa Earth Science, 16(3), 309-317. http://dx.doi.org/10.1016/0899-5362(93)90051-Q

Philip, K. (2001). Dictionary of Geology (2nd ed, p. 117).

Prasad, N. N. (2011). Geophysical investigation for groundwater exploration in Lakshadweep Islands - A case study. J. Ind. Geophys. Union., 15(4), 221-227.

Telford, W. W. M., \& Sheriff, R. E. (1990). Applied geophysics (Vol. 1). Cambridge University Press. http://dx.doi.org/10.1017/CBO9781139167932

William, L. (1997). Fundamentals of Geophysics. Cambridge, UK: Cambridge University press.

Zohdy, A. A. R. (1989). A New Method for the Automatic Interpretation of Schlumberger and Wenner sounding curve. Geophysics, 54, 245-253. http://dx.doi.org/10.1190/1.1442648

\section{Copyrights}

Copyright for this article is retained by the author(s), with first publication rights granted to the journal.

This is an open-access article distributed under the terms and conditions of the Creative Commons Attribution license (http://creativecommons.org/licenses/by/3.0/). 